Available online at GSC Online Press Directory

GSC Biological and Pharmaceutical Sciences

e-ISSN: 2581-3250, CODEN (USA): GBPSC2

Journal homepage: https://www.gsconlinepress.com/journals/gscbps

(RESEARCH ARTICLE)

\title{
Chemical and microbiological hazards of Khat (Catha edulis) from field to chewing in Ethiopia
}

\author{
Beyene Wondafrash Ademe ${ }^{1,}{ }^{*}$, Leon Brimer ${ }^{2}$, Anders Dalsgaard ${ }^{2}$ and Tefera Belachew ${ }^{3}$ \\ 1 Department of Nutrition and Dietetics, Health Sciences Institute, Jimma University, Ethiopia. \\ ${ }^{2}$ Department of Veterinary and Animal Sciences, Faculty of Health and Medical Sciences, University of Copenhagen, \\ Denmark. \\ ${ }^{3}$ Department of Nutrition and Dietetics, Health Sciences Institute, Jimma University, Ethiopia.
}

Publication history: Received on 10 February 2020; revised on 02 April 2020; accepted on 04 April 2020

Article DOI: https://doi.org/10.30574/gscbps.2020.11.1.0038

\begin{abstract}
Catha edulis of the plant family Celastraceae commonly named as Khat in Ethiopia is a stimulant plant containing amphetamine-like substances. Fresh Khat leaves described to contain some 60 different constituents. Consumers chew leaves and masticate it for hours. Some users make a paste from dried leaf powder, mixing with sugar and water which is easily chewed and swallowed. In some areas, dried leaves are used as a tea, and also crushed and rolled into cigarettes. Less attention has been directed toward possible chemical and microbial contamination and risky pathways. The aims of this study are 1.Identify the actual Khat production-consumption process from farm to use. 2. Detect chemical and microbial contamination risk of consumable Khat leaf in process 3. Assess the microbiological qualities chewable Khat leaf. Descriptive statistics from the main dataset, for Khat consumption, showed that out of 1169,564 household heads were Khat consumers and out of these consumers, 347 (62.52\%) consume daily. Majority of the pilot study participants (retailers and consumers) confirmed that pesticide chemicals are sprayed on Khat bushes and trees, and Khat farmers disclosed the use of Dichlorodiphenyltrichloroethane (DDT) and Malathion on their farm. The mean CFU/gm was $1.69^{*} 10^{\wedge} 5$ which indicate poor hygiene /handling. Our observation showed that the processes from farming, Transporting, collection, distribution (whole-sellers, retailers) to consumption indicate a potential risk for Khat leaf to become contaminated with Chemicals/ microorganisms.
\end{abstract}

Keywords: Khat production and consumption Flowchart; DDT; Malathion; Microorganisms; CFU

\section{Introduction}

Catha edulis Forsk of the plant family Celastraceae (Spindle-tree) commonly named as Khat in Ethiopia is an amphetamine-like stimulant plant widely consumed in Eastern Africa and southern Arabian region [1, 2]. According to a recent phylogeography study, the primary sources of wild and cultivated Khat genotypes centres of origin are Ethiopia and Kenya [3], from where it spread to countries such as Yemen, Uganda, and Madagascar [4]. Fresh Khat leaves could contain around 60 secondary substances [5]. Main constituents are cathine (S, S- $(+)-$ nor-pseudoephedrine) and cathinone (S- (-)- $\alpha$-amino-propiophenone) [6]. Around 400 million people in the Horn of Africa and the Arabian Peninsula are using Khat leaves and Khat chewing has been a social custom for centuries [7].

Humans have for centuries used a variety of sedatives, narcotics, hallucinogens, antidepressants, and stimulant herbs and Khat is among them. More research outputs are available about the pharmacologic, physiological and psychological effect of Catha edulis. The adverse effects of Khat use and abuse such as oral, gastrointestinal, cardiovascular, neurological, psychiatric, hepatotoxicity, cytotoxicity have also been studied [8]. Khat's social status and recreational

\footnotetext{
* Corresponding author: Beyene Wondafrash Ademe E-mail: beyenewondafrash@gmail.com
} 
use as a traditional herb have hindered the knowledge about its harm in terms of morbidity and mortality and less attention has been directed towards possible chemical and microbial contamination of chewable Khat leaf.

Research findings indicated illness and death case reports associated with Khat consumption. However, further study should be done to ascertain the exact role of Khat chewing in such pathologies. Death due to Endocarditis caused by bacterium Gemella morbillorum [9], blood infection with bacteria Campylobacter fetus, duodenal ulcer due to Helicobacter pylori colonization [10,11], severe liver fibrosis and cirrhosis [12], severe liver injury from Khat abuse resulting in liver transplantation [13], infection from Fasciola hepatica (parasitic flatworm) [14], high incidence of oral squamous cell carcinoma [15], a decrease in cell viability and an increase in cell apoptosis, alteration of the effectiveness of immune activity of peripheral blood mononuclear cells (PBMCs) [16], jaundice, coma and death from toxicity[17], increased risk of Mycobacterium tuberculosis infection through its active ingredient (cathinone) macrophage immune modulation action [18].

During harvesting Khat leaves and shoots of the shrub are handpicked, huddled and wrapped up with banana leaves and are often kept in moistened conditions for up to 48 hours before consumption [19]. Farmers and traders deliver the leaves to the point of sale carried by humans, animals or open tracks in unhygienic condition. Usually, young fresh leaves that are valued for their stimulant potency are picked in the morning and chewed on the same day. During chewing; leaves are placed in the buccal fold and masticated for several hours. Some users make a paste from dried leaf powder, mixing with sugar and water, which is easily chewed and swallowed. In some areas, dried leaves are used as a tea. Leaves also crushed and rolled into cigarettes [20,21]. In Kenya, efforts are made to promote Khat as tea-sachets, bottled juice as well as an ingredient in wine [21,22]

Khat farmers in Ethiopia use organophosphate pesticides, such as Malathion, Diazinon, and organochlorine-DDT for pest control, and users could ingest pesticides sprayed on Khat field. There were death reports that were due to poisoning following the ingestion of pesticides used on the Khat tree. Diazinon levels from Khat analysis, grown from South West Ethiopia (Jimma) detected 173.9-751.4 $\mu \mathrm{g} / \mathrm{kg}$, which is high compared to the level of $10 \mu \mathrm{g} / \mathrm{kg}$ set for vegetables and fruit by the European Union (EU) [23].

Although the 1970 commitment and 2001 "Stockholm Convention on Persistent Organic Pollutants" banned DDT [24], Khat farmers confirmed that DDT is also sprayed on their Khat plant, accessed during outdoor spray for Anopheles mosquito eradication [25] or from chemical shops. Khat analysis from Eastern Ethiopia (Hararge) localities also showed that the average residue Level of DDT observed in three Khat samples were 1224,1372 and $1163 \mu \mathrm{g} / \mathrm{Kg}$ which is much higher than the EU M Maximum Residue Levels (MR)L for citrus fruits, vegetables and sugar plants (10 $\mu \mathrm{g} / \mathrm{Kg})$. From Southwest Ethiopia, near Jimma town (Badabuna), Diazinon was also detected in all the Khat samples with an average of $500 \mu \mathrm{g} / \mathrm{Kg}$ (range $200-800 \mu \mathrm{g} / \mathrm{kg}$ ) which were above the set for vegetables by EU [26].

Mycotoxins producing toxigenic fungi were also isolated from Khat leaf. A study was done in Yemen (around Sana'a), from 30 samples of chewable Khat leaves, and eleven mycotoxigenic fungi from which Aspergillus, Alternaria, Penicillium, and Cladosporium were the most frequent genera. This finding was considered to be a threat to public health [27]

It is well-established that the contamination of raw vegetables with various pathogens is associated with human gastrointestinal disease outbreaks, particularly bacterial pathogens of the Enterobacteriaceae family [28]. Microbial pathogens, spoilage bacteria, fungi, and parasites found on any ready-to-eat vegetables could also be present on Khat leaves posing an infection risk to the Khat consumers [29]. Khat leaf laboratory analysis in Ethiopia (Hawassa: the capital city of SNNP) from 51 Khat samples, 29 had aerobic mesophilic counts with the mean count of $7.2 \mathrm{x} 10^{5} \mathrm{cfu} / \mathrm{g}$. Enterobacteriaceae and bacterial spores had mean counts of around $104 \mathrm{CFU} / \mathrm{g}$ and Staphylococcus sp., Bacillus cereus, and yeasts and moulds had counts of $103 \mathrm{CFU} / \mathrm{g}$. according to this finding Khat consumption was considered hazardous [30].

This paper is not about the wider phenomenon of morbidity and mortality linked to Khat consumption. But by revealing case reports, actual practices and processes of the plant cultivation and use, it is hoped that this information will be noted by agricultural extension experts, Khat using communities, and health professionals.

\subsection{Objective}

The objective of this study was to identify and evaluate chemical and microbiological hazards along the chain of Khat production in the field to human consumption. 


\section{Material and methods}

\subsection{Study area}

The pilot study was conducted in Jimma Town, located $350 \mathrm{~km}$ southwest of the capital Addis Ababa. The town is divided into 17 kebeles (smallest administrative units in Ethiopia). According to the 2012 Central Statistical Agency census report [31], the projected total population of the town is 134,040 . The town is generally characterized by a warm and humid climate.

\subsection{Method}

This study was undertaken within Empowering New Generations to Improve Nutrition and Economic Opportunities' (ENGINE) project sites which envision bringing sustainable improvement in the nutritional status of rural households in Ethiopia. We reviewed literature evidence and case reports on Khat use related health outcomes; i.e. pesticides contaminants and microbiological contaminations. A baseline study conducted to understand the Khat productionconsumption process so as to account for chemical and microbial analysis of consumable Khat leaf. Piloting was done from five Khat farm sites, five Khat retailers and five consumers respectively. In addition, five chemical shops in Jimma town were visited and interviewed. Observation guide from production to consumption was used to explore Khat cultivation, processing and consumption practices related risks by using a flow diagram. The Hazard Analysis Critical Control Points (HACCP) approach was used to identify the hazards of chemical and microbiological risky pathways from farm to use. HACCP helps to determine the corrective measures for situations where critical control points are beyond control limits [32] Estimated daily intake (EDI) of pesticides from consumable Khat leaf was assessed by extrapolating pesticides database [33] and from previous studies conducted in Ethiopia on pesticide residues from Khat leaf.

For the microbial quality of consumable Khat leaf study, a total of 10 bunch (locally named as Zurba) of fresh chewable Khat leaves were purchased and collected in sterile plastic bags from 10 retail market points of Jimma town(southwest Ethiopia), and directly brought to the laboratory, processed and analyzed for their microbial load. From each of the 10 sample lot, $5 \mathrm{gm}$ of fresh chewable Khat leaves were mixed with $100 \mathrm{ml}$ of $1 \%$ buffered peptone water in a sterile plastic bag; shaken and squeezed intermittently for over 2-3 minutes to obtain a homogenized stock solution and to find viable cells from the leaf surface. Dilutions were done taking $1 \mathrm{ml}$ from the stock. $100 \mu \mathrm{l}$ diluted solution from each Serial $\left(10^{-1}\right.$ to $10^{-7)}$ were subcultured on indicative agars Rapid E. coli plates ( 7 duplicated plates and 1 control). The 15 plates were incubated overnight at $37^{\circ} \mathrm{c}$. The colony was counted by colony counter (magnifier). The microbiological qualities of sampled chewable Khat leaf were assessed as the Total Viable Count (TVC) which measures only viable CFU cells of large group of bacteria that could contain certain pathogenic bacteria, which are relatively easy to measure as a group and their presence in chewable Khat is likely to indicate the presence of pathogenic bacteria as Indicator organisms.

Table 1 Methodology summary

\begin{tabular}{|c|c|c|c|c|c|c|c|c|}
\hline $\begin{array}{c}\text { Research } \\
\text { Objectives }\end{array}$ & $\begin{array}{l}\text { Study } \\
\text { area }\end{array}$ & $\begin{array}{l}\text { Sample } \\
\text { size }\end{array}$ & $\begin{array}{l}\text { Sampling } \\
\text { method }\end{array}$ & $\begin{array}{l}\text { Study } \\
\text { design }\end{array}$ & $\begin{array}{c}\text { Study } \\
\text { variables }\end{array}$ & $\begin{array}{c}\text { Data } \\
\text { source }\end{array}$ & $\begin{array}{c}\text { Main } \\
\text { outcome }\end{array}$ & $\begin{array}{l}\text { Analytic } \\
\text { method }\end{array}$ \\
\hline $\begin{array}{c}\text { To identify } \\
\text { chemical and } \\
\text { microbial } \\
\text { exposure } \\
\text { associated } \\
\text { with Khat } \\
\text { production } \\
\text { and } \\
\text { consumptio } \\
\text { n processes } \\
\text { and } \\
\text { practices }\end{array}$ & $\begin{array}{l}\text { Jimma } \\
\text { town } \\
\text { Khay } \\
\text { sale } \\
\text { points } \\
\text { and } \\
\text { nearb } \\
\text { y rural } \\
\text { farms }\end{array}$ & $\begin{array}{c}10 \text { Khat } \\
\text { samples, } \\
5 \text { Khat } \\
\text { farm, } \\
5 \text { Khat } \\
\text { retailers } \\
\text { and } \\
5 \\
\text { Consumer } \\
\text { s }\end{array}$ & $\begin{array}{l}\text { Convenient } \\
\text { sampling, } \\
\text { observatio } \\
\text { n guide and } \\
\text { process } \\
\text { flowchart }\end{array}$ & $\begin{array}{c}\text { Khat } \\
\text { supernatan } \\
t \\
\text { lab.culture, } \\
\text { Baseline } \\
\text { assessment } \\
\text { \&HACCP } \\
\text { model } \\
\text { approach } \\
\text { (cross- } \\
\text { sectional) }\end{array}$ & $\begin{array}{l}\text { Observation } \\
\text { \& flowchart } \\
\text { variables } \\
\text { (chemical } \\
\text { shops, leaf } \\
\text { picking } \\
\text { \&preparation } \\
\text {, storage, } \\
\text { transport, } \\
\text { manure } \\
\text { usage); CFU } \\
\text { culture; } \\
\text { pesticide } \\
\text { reference } \\
\text { values (ADI, } \\
\text { ARfD, MRLs) }\end{array}$ & $\begin{array}{l}\text { Khat retail } \\
\text { points, } \\
\text { interview } \\
\text { s and } \\
\text { pesticides } \\
\text { databases }\end{array}$ & $\begin{array}{l}\text { Chemical } \\
\text { and } \\
\text { microbial } \\
\text { risks of Khat } \\
\text { production } \\
\text { and } \\
\text { consumptio } \\
n\end{array}$ & $\begin{array}{c}\text { Quantifying } \\
\text { the lab } \\
\text { culture and } \\
\text { Hazard } \\
\text { identificatio } \\
n\end{array}$ \\
\hline
\end{tabular}




\subsection{Study Ethics}

Ethical approval was obtained from the ethical clearance committee of Institute of health science of Jimma University institutional review board. After receiving ethical clearance, informed verbal consent was obtained from each study participant. Personal identifying information was not included in the questionnaire, and the observations and interviews remained confidential.

\section{Results}

Descriptive statistics from the main dataset, for Khat consumption, showed that out of 1169,564 household heads were Khat consumers and out of these consumers, Majority, 347 (62.52\%) chewers consume daily. Most, 313 (57.30\%) consume for social setting or community social activities followed by 313 (56.4\%) who reported to enhance working capacity and $165(29.73 \%)$ referred to religious reasons.

The baseline survey from Khat production farm sites demonstrates that most Khat plantation plots are located around the homesteads where manures, human and animal wastes are used as fertilizers. Leaves and sprouts were hand-picked, sealed with banana leaves, and transported by open vehicles, animals or humans to point of sale. We confirmed that Khat leaf for consumption is not washed or otherwise cleaned before being chewed. Our observation showed that the processes from farming, collection, Transporting, distribution (whole-sellers, retailers) to consumption indicate a potential risk for Khat leaf to become contaminated with Chemicals/ microorganisms. (Table 2)

Table 2 Observations/measurements of Khat production/consumption practices

\begin{tabular}{|c|c|c|}
\hline Variable & Indicator & Method \\
\hline Khat farm & Cultivation, nursery and type of agricultural inputs used & Observation \\
\hline Local pesticide retail shops & Type and availability of chemicals & $\begin{array}{l}\text { Observation } \\
\text { Interview }\end{array}$ \\
\hline Khat leaf collection/picking & $\begin{array}{l}\text { Hand picking, storage area \& container, hygiene } \\
\text { conditions }\end{array}$ & Observation \\
\hline $\begin{array}{l}\text { Personal hygiene and Hygienic } \\
\text { conditions during consumption }\end{array}$ & $\begin{array}{l}\text { Hand washing habit, availability of water for hand } \\
\text { washing }\end{array}$ & Observation \\
\hline Khat Leaf preparation for sale & $\begin{array}{l}\text { Place of preparation, Steps of preparation and activities. } \\
\text { Hygienic conditions. }\end{array}$ & Observation \\
\hline $\begin{array}{l}\text { Transportation } \\
\text { auction/retail sites }\end{array}$ & $\begin{array}{l}\text { Transport means (human, animal, and vehicle) and } \\
\text { activities. Hygienic conditions. }\end{array}$ & Observation \\
\hline Storage conditions & $\begin{array}{l}\text { Storage materials and processes, time of storage. Hygienic } \\
\text { conditions. }\end{array}$ & Observation \\
\hline Weed, compost and manure use & Ways of the application during Khat cultivation & Observation \\
\hline $\begin{array}{l}\text { Conditions at the distribution } \\
\text { points }\end{array}$ & $\begin{array}{l}\text { Sale points and conditions, possible contamination points } \\
\text { (refuse dump near sale points, animals around vendors, } \\
\text { roadsides with dust) }\end{array}$ & Observation \\
\hline Khat chewing sessions & $\begin{array}{l}\text { Place of session, leaf serving procedure, amount of leaf, } \\
\text { group of consumers, groundnuts and drinks served. } \\
\text { Hygienic conditions. }\end{array}$ & $\begin{array}{l}\text { Observation } \\
\text { Sampling \& }\end{array}$ \\
\hline Microbial quality assessment & CFU from edible Khat leaf samples at 10 retail sites & Measurement \\
\hline
\end{tabular}


As shown in the flowchart (Figure 1), Khat Farming, collecting, preparation, transporting, retail and consumption contains hazards for the end-users (consumers). Chemicals such as DDT and Malathion are sprayed for pest control at different seasons. A variety of pesticides were on sale from chemical shops. There are individuals who own sprayer jar with pesticides and enter a contract with Khat farmers to do the spraying.

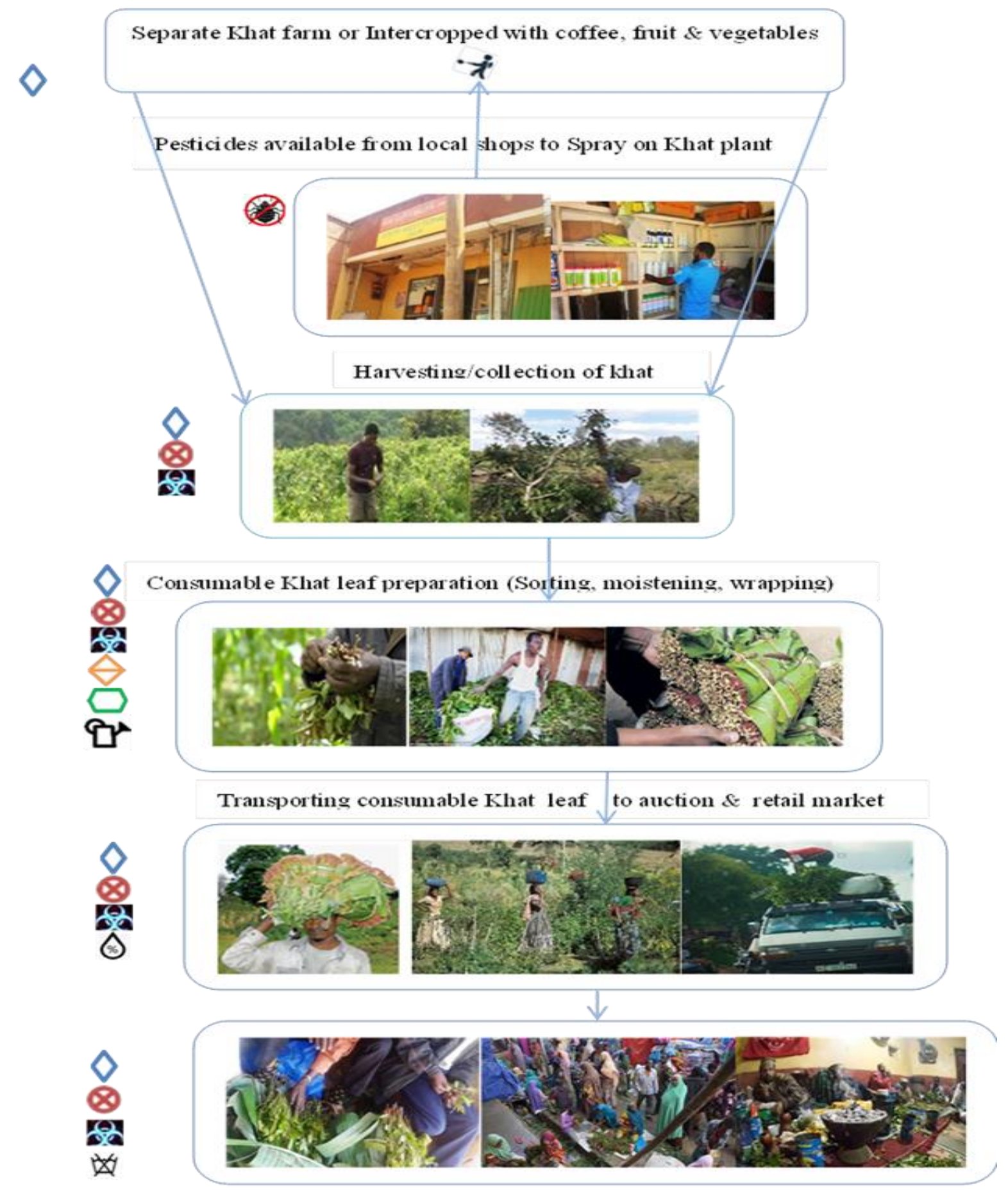

Figure 1 Khat Farming, collecting, preparation, transporting, retail and consumption flow chart

\section{Legend for figure 1}

$\checkmark$ Initial contamination with waste manures (human \& animal) \& plant debris

Available Local chemical shops 


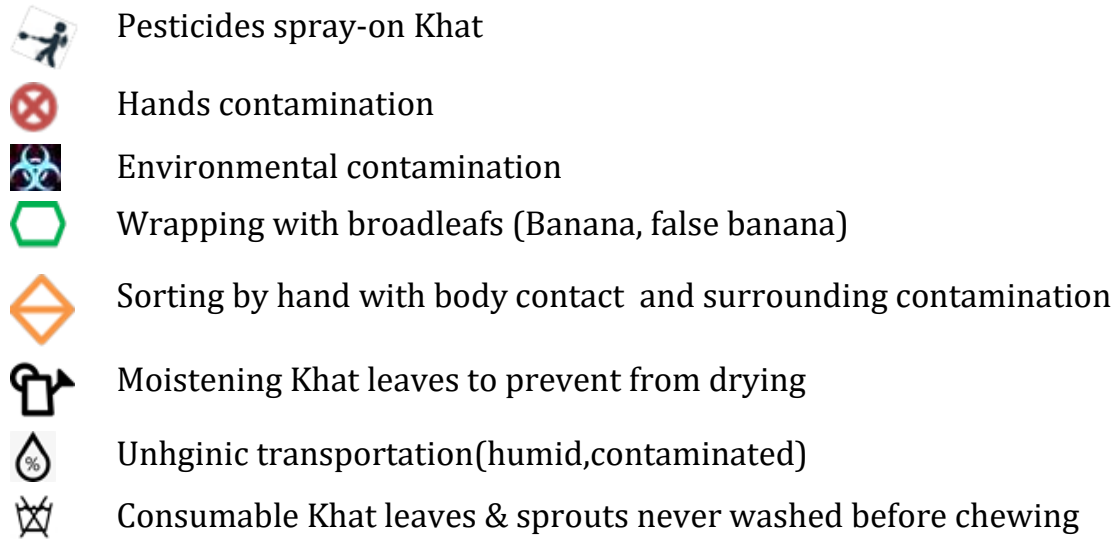

At chemical shops available in Jimma Town we observed various pesticides stocks such as Malathion 50 Emulsifiable Concentrate, Endosulphan35\%, Chlorpyriphos 48, 2 Emulsifiable Concentrate and DDT (concealed from the shelf to be offered on request); Herbicides such as 2, 4-D-dimethylamine salt, Glyphosate48\%SL; Fungicides such as Curazate $\AA$ RWP, Trust cymocop®439.5 WP, Matco.8-64, and Indofil M-45 are also on the shelf.

DDT products are also available in chemical shops in our research site (Jimma town). (Figure 2) Our pilot interview and observations in Khat fields verified that DDT is sprayed on Khat trees and bushes. Customers are farmers from outside the town and shopkeepers' recommend/advice which chemicals to purchase for Khat spray.

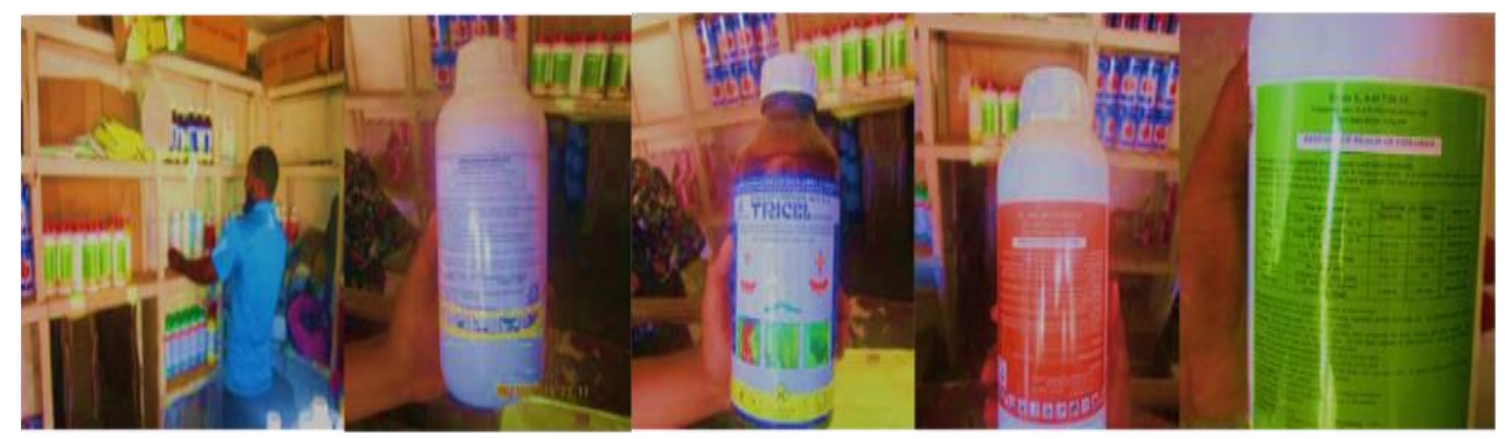

Figure 2 Pesticide retail shops from the research site (shop; Malathion; Chlorpyriphos 48E.C; Endosulphan 35\%; 2-4D-dimethylamine salt). The photo was taken by the author, October 2016.

Local retailers and habitual consumers confirmed that 'Khat leaves which are sprayed with DDT appear clean and shiny; causes burning sensation on the lips and mouth while chewing and the twig and leaves have no signs of insect bite'. (Fig 3)

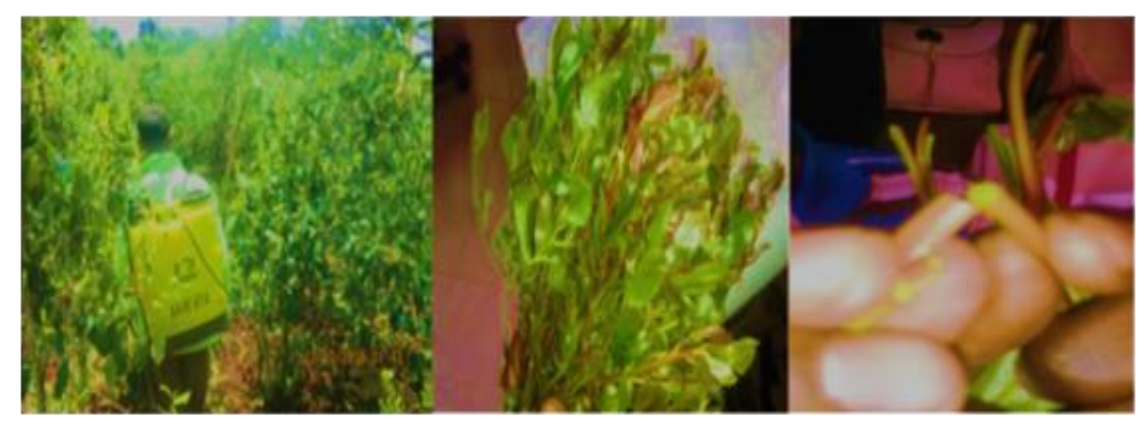

Figure 3 Field observations during Pesticide spray-on Khat plant and sign of pesticides prayed leaf demonstrated by the retailer... The photo was taken by the author, October 2016.

Retailers had knowledge of the use of pesticides on Khat. Khat traders confirmed that Khat was neither washed nor otherwise cleaned before being delivered for sale or during consumption. The reason behind this assertion was the 
assumption to keep the natural flavour of the chewable Khat. Consumable fresh Khat leaf is delivered, from whole sellers or individual farmers, daily from 11am to early evenings. (Figure 4) Depending on popularly used Khat variety, 500g wrapped bundles, priced between USD2-5.

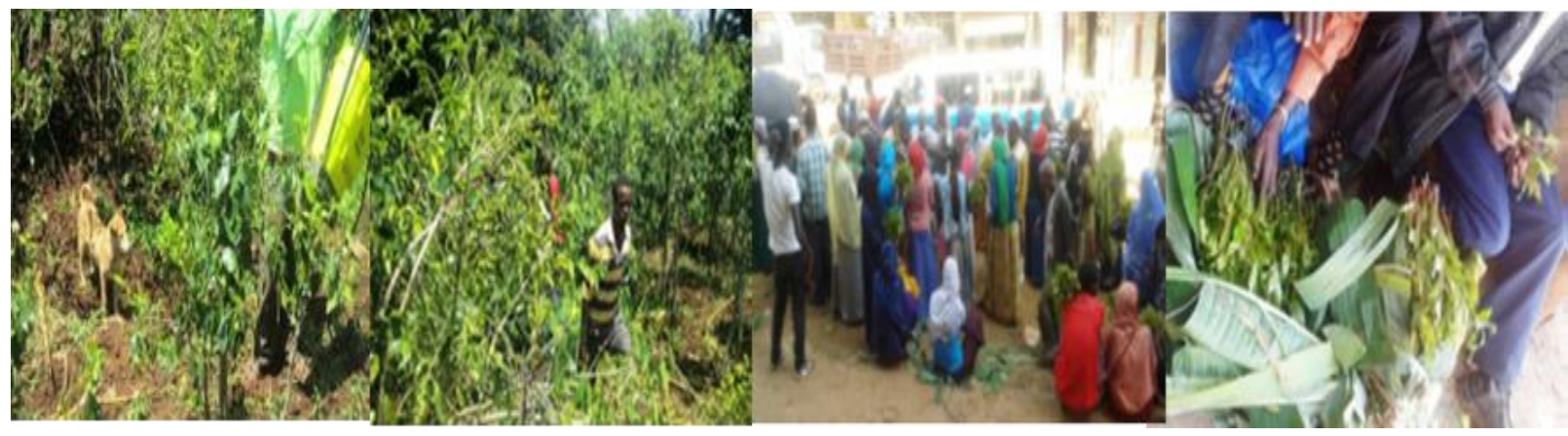

Figure 4 Unhygienic conditions from farm site, sampling retail spot, and local Khat market in Jimma Town. The photo was taken by the author, December/2016.

The primary Khat customers were predominantly adult males. Whole fresh leaves and buds are chewed immediately after purchase without cleaning. Even though consumers know about chemical spray on Khat and even differentiate the sprayed ones from not sprayed they showed no concern about the health risks of Khat use.

During baseline/pilot information collection process the practice of the chemical application on Khat bush/tree was witnessed. Khat farmers had access to pesticides from local shops or directly from sprayers. DDT and Malathion were the most frequently applied pesticides. We observed that Khat plant is intercropped with other perennial and seasonal crops and pesticides are sprayed on all plants indiscriminately which implies the risk of contamination on other crops as well.

As shown in (Table 4) the concentration of pesticide in the Khat leaf (mg/kg) is taken from published articles or set to be equivalent to MRLs database for other crops [34]. Based on the baseline information and previous investigations [35] the average fresh weight of Khat consumption is $0.15 \mathrm{~kg} / \mathrm{day}$. For an adult having a bodyweight of $60 \mathrm{~kg}$ the mean value for the daily intakes of a given pesticide can be calculated as follows;

$$
\mathrm{EID}=\frac{\text { Conc. } P \times W}{C \cdot A v g \cdot W t}
$$

Where,

EID= Estimated daily intake (EDI) in $\mathrm{mg} / \mathrm{kgbw} /$ day

Conc. $P=$ concentration of pesticide in Khat leaf $(\mathrm{mg} / \mathrm{kg})$

$W=$ Weight of Khat chewed in $\mathrm{kg}$

C.Avg.Wt= average wt. of consumers

Accordingly, DDT residue exposure is calculated to be $0.003 \mathrm{mg} / \mathrm{kg} \mathrm{BW} /$ day. Compared to ADI \&MRLs set values it is lower. However, this may not guarantee safety, and the fact that (a) Khat is a permanent crop and is sprayed frequently (2-3times per year) (b) Habitual chewers use it on daily basis, for longer hours over the years, (c) Khat is consumed fresh-raw with no washing or any sort of cleaning, and (d) DDT is a persistent organic pollutant, bio-accumulative and toxic it can create adverse effects upon Khat chewers and the natural environment. On the other hand, a study from western Ethiopia localities measured $1.3 \mathrm{mg} / \mathrm{kg}$ of Khat DDT residue which is higher than MRLs set values. Diazinon residue exposure is calculated to be $0.02 \mathrm{mg} / \mathrm{kg}$ BW/day. Compared to ADI set values $(0.0002 \mathrm{mg} / \mathrm{kg} \mathrm{BW} / \mathrm{day})$ it is a hundred times higher. A study was done around Southwest Ethiopia (Jimma) town revealed Diazinon level of 0.75 $\mathrm{mg} / \mathrm{kg}$ of Khat which is higher than MRLs set values $(0.1 \mathrm{mg} / \mathrm{kg}$ for blackberries \& $0.5 \mathrm{mg} / \mathrm{kg}$ for Lettuce. 
Table 4 Estimated Khat pesticide exposure extrapolated from thresholds for the common pesticides exposure (Values from European Union (EU) \& FAO Codex Alimentarius Pesticides database)

\section{Common pesticides sprayed on Khat}

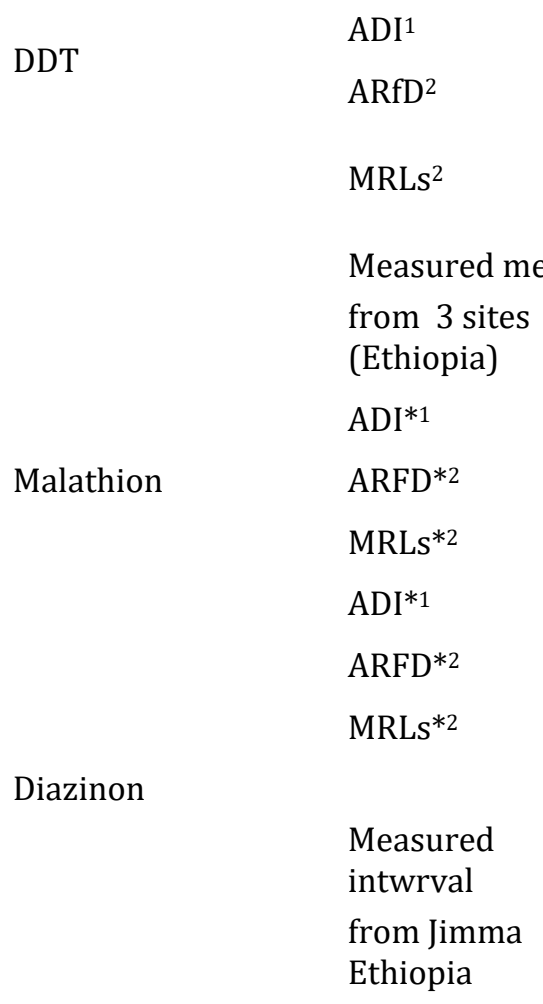

${ }^{1}$ Values from European Union (EU) pesticide database ${ }^{2}$ Values from Codex alimentarius pesticide database

Acceptable Daily Intake (ADI): An estimate of the amount of a substance in food or drinking water that can be consumed daily over a lifetime without presenting an appreciable risk to health (WHO, 1987).It is derived from long-term animal (in vivo) studies (NOAEL).

Acute Reference Dose (ARfD): An estimate of the amount of a substance in food or drinking Water that can be ingested over a short period of time, usually during one meal or one day, Without appreciable health risk to the consumer on the basis of all known facts at the time of evaluation. It has decreased margin of safety (JMPR, 2002)

No Observed Adverse Effect Level (NOAEL): It is the value taken from tests with animals or epidemiological data to determine the TDI Identified in the critical studies. This value is then divided by a safety factor (usually 100) which is intended to take into account the different levels of sensitivity between humans and animals

Tolerable daily intake (TDI): The daily amount of a chemical that has been assessed safe for human being on long-term basis (usually whole lifetime) A maximum residue level (MRL): The highest level of a pesticide residue that is legally tolerated in or on food or feed when pesticides are applied correctly (Good Agricultural Practice)

Application of pesticides applied on Khat extends to other crops, and it is likely that the actual daily intake may be higher due to additional exposure through other food consumption. This directs the need for awareness creation among the people in the community and the need for launching community-based education programs through local health care and agricultural professionals, educators, development agents, administrative bodies and researchers.

Laboratory analysis for microbial contamination of chewable Khat showed that there is infection risk to the consumers. From 10 Khat sample lots, we have determined the presence of coliform as an indicator of microbiological quality. Indicator organisms (CFU) were isolated from all the 3 consecutive serial dilutions of the 10 samples of 30 RAPID'E.coli2 plates; ranging from $15-389 \mathrm{cfu} / 100 \mu \mathrm{l}, 8-50 \mathrm{cfu} / 100 \mu \mathrm{l}$, and $1-19 \mathrm{cfu} / 100 \mu \mathrm{l}$ with mean of $136 \mathrm{cfu} / 100 \mu \mathrm{l}, 28 \mathrm{cfu} / 100 \mu \mathrm{l}$ and $9 \mathrm{cfu} / 100 \mu \mathrm{l}$ respectively. Similarly, the mean CFU/gm was $1.69 * 10^{\wedge} 5$. The result showed higher microbial loads which are an indication of poor hygiene or handling practices or unhygienic condition of processing, handling, and consumption of chewable Khat leaves. 
Table 5 Colony forming units in the 3 serial dilutions and mean CFU/g

\begin{tabular}{|c|c|c|c|c|c|c|}
\hline $\begin{array}{l}\text { Dilution1 } \\
\text { cfu/100 } \boldsymbol{\mu l}\end{array}$ & $\begin{array}{l}\text { Dilution2 } \\
\text { cfu/100 } \mathrm{\mu l}\end{array}$ & $\begin{array}{l}\text { Dilution3 } \\
\text { cfu } / 100 \mu l\end{array}$ & D1-D3 & $\mathrm{CFU} / \mathrm{g}$ & Deviation & SD \\
\hline 192 & 26 & 9 & 227 & $2.28 \mathrm{E}+05$ & $2.28 \mathrm{E}+05$ & $3.50 \mathrm{E}+09$ \\
\hline 139 & 34 & 6 & 179 & $1.80 \mathrm{E}+05$ & $1.80 \mathrm{E}+05$ & $1.20 \mathrm{E}+08$ \\
\hline 74 & 12 & 3 & 89 & $8.94 \mathrm{E}+04$ & $8.94 \mathrm{E}+04$ & $6.32 \mathrm{E}+09$ \\
\hline 389 & 35 & 19 & 443 & $4.45 \mathrm{E}+05$ & $4.45 \mathrm{E}+05$ & $7.63 \mathrm{E}+10$ \\
\hline 316 & 50 & 12 & 378 & $3.80 \mathrm{E}+05$ & $3.80 \mathrm{E}+05$ & $4.45 \mathrm{E}+10$ \\
\hline 24 & 8 & 1 & 33 & $3.32 \mathrm{E}+04$ & $3.32 \mathrm{E}+04$ & $1.84 \mathrm{E}+10$ \\
\hline 93 & 24 & 19 & 136 & $1.37 \mathrm{E}+05$ & $1.37 \mathrm{E}+05$ & $1.04 \mathrm{E}+09$ \\
\hline 73 & 14 & 5 & 92 & $9.24 \mathrm{E}+04$ & $9.24 \mathrm{E}+04$ & $5.85 \mathrm{E}+09$ \\
\hline 45 & 16 & 14 & 75 & $7.53 \mathrm{E}+04$ & $7.53 \mathrm{E}+04$ & $8.75 \mathrm{E}+09$ \\
\hline \multirow[t]{3}{*}{15} & 8 & 6 & 29 & $2.91 E+04$ & $2.91 \mathrm{E}+04$ & $1.95 \mathrm{E}+10$ \\
\hline & \multicolumn{3}{|c|}{ Mean CFU } & $\underline{1.69 E+05}$ & SMSQ & $1.84 \mathrm{E}+10$ \\
\hline & & & & & SD & $1.36 \mathrm{E}+05$ \\
\hline
\end{tabular}

\section{Discussion}

In many Khat production areas in Ethiopia, its production and consumption are integrated into the culture, economy, and livelihoods of rural households. Consumers chew its leaves, buds and soft stems frequently and for a long hour as raw, without any processing, washing or cleaning it before consuming [35].

Our baseline study showed that during Khat production and consumption process there is no even minimal processing of any kind. Khat leaves are handpicked, sorted and wrapped by broad leaves or grasses. After transported under unhygienic conditions the sprouts and leaves are retailed at open markets and verandas. In such processes contamination at every step was evident. Risk (R=P*I) assessment as an outcome of the interaction between probability and Impact (likelihood) [35], can be used to evaluate the health and safety impact of chemical and microbial risks of Khat chewing. But the Khat issue does not exist in isolation. A holistic approach by understanding the interaction among psychological, social, institutional, cultural, and economic aspects of Khat agriculture and use should be understood. These interactions may amplify or mitigate public responses to the risk events. Discussions of event identification and risk response are beyond the scope of this paper .

Studies showed that Khat consumption practice was associated with unacceptable levels of microbial and chemical contamination. Wrong application of pesticides, particularly on Khat plant, which is consumed regularly and raw could lead to serious health effects on consumers. To asses consumer exposure to pesticide and the level of pesticide consumption risk, there should be made an investigation on the Acceptable Daily Intakes ( mg/kgbw) (ADI), Acute Reference Dose (mg/kgbw) (ARFD), and whether pesticide concentration exceeds the toxicological threshold or the MRLs (mg/kg Khat consumed) for such routine exposure[36, 37].

Vegetables and their leaf ecology provide nutrients, moisture and favourable pH for microbial pathogen species of Shigella, Salmonella, Aeromonas and Yersinia together with Clostridium botulinum, Listeria monocytogenes, Staphylococcus aureus, Bacillus cereus, which can cause food-borne illness. Minimal processing of vegetables (sanitizing, washing, freezing trimming) is often challenged by the microflora density, diversity and growth, not only on the surface but also by biofilm formation deep in the cellular structure of their veins, cuticle, depression of the stomata, or in the intercellular junction [38]

The purpose of the laboratory culture was to assess the microbiological quality of chewable Khat leaf. Following the standard operating procedure Indicator organisms (CFU) were isolated from all the 10 samples of 30 RAPID'E.coli2 plates (100\%). A colony could arise from one cell or several thousand cells and CFU can be influenced by the colony morphology and colony density. 


\section{Conclusion}

Microbial pathogens (bacteria, virus, fungi, and parasites) and pesticide residues can be present on chewable Khat leaves and health risk to the consumers could be imminent.This Study showed that Khat consumption practice was associated with unacceptable levels of microbial and chemical contamination. Habitual consumers shall be aware of the risk of Khat chewing from an infectious risk perspective and possible chemical contaminants exposure side effects as well.

\section{Compliance with ethical standards}

\section{Acknowledgments}

We are grateful to Khat farmers, retailers and chemical shopkeepers for providing the necessary information.

\section{Disclosure of conflict of interest}

The authors declare that they have no competing interests.

\section{Statement of ethical approval}

Ethical approval was obtained from the ethical clearance committee of Institute of health science of Jimma University institutional review board. After receiving ethical clearance, informed verbal consent was obtained from each study participant. Personal identifying information was not included in the questionnaire, and the observations and interviews remained confidential.

\section{References}

[1] Ageely HM. (2008). Health and socio-economic hazards associated with Khat consumption. Journal of family \& community medicine, 15(1), 3-11.

[2] Balint EE, Falkay G and Balint GA. (2009). Khat-a controversial plant. Wiener klinische Wochenschrift, 121(1920), 604-614.

[3] Tembrock LR, Simmons MP, Richards CM, Reeves PA, Reilley A, Curto MA, Meimberg H, Ngugi G, Demissew S, Al Khulaidi AW, Al-Thobhani M, Simpson S and Varisco DM. (2017). Phylogeography of the wild and cultivated stimulant plant qat (Catha edulis, Celastraceae) in areas of historical cultivation. American Journal of Botany, 104(4), 538-549.

[4] Njiru N, Muluvi A, Owuor G and Langat J. (2013). Effects of Khat Production on Rural Household's Income In Gachoka Division Mbeere South District Kenya. Journal of Economics and Sustainable Development, 4(2), 54-63.

[5] Klein A. (2014) Framing the Chew: Narratives of Development, Drugs and Danger with Regard to Khat (Catha edulis). Prohibition, Religious Freedom, and Human Rights: Regulating Traditional Drug Use. Springer, 131-147.

[6] Patel N. (2000) Mechanism of action of cathinone: the active ingredient of Khat (Catha Edulis. East African medical journal, 77(6), 329-332.

[7] Kirwan BE and Mcmillan M. (2007). Food aid and poverty. American Journal of Agricultural Economics, 89(5), 1152-1160.

[8] Thomas S and Williams T. (2013). Khat (Catha edulis): A systematic review of evidence and literature pertaining to its harms to UK users and society. Drug Science, Policy and Law, 1, 20-50.

[9] Massoure PL, Lions C, Caumes JL, Spadoni S, Gaillard PE and Bougere J.(2010). Lethal aortic endocarditis due to Gemellamorbillorum in a Djiboutian Khat user. La Revue de medicine interne, 31(8), 7-9.

[10] Martínez-Balzano C, Kohlitz PJ, Chaudhary P and Hegazy H. (2013) .Campylobacter fetus bacteremia in a young healthy adult transmitted by Khat chewing. Journal of Infection, 66, 184-186.

[11] Raja'a Y, Noman T, AL-Warafi A, Al Mashraki N and Al Yosofi A. (2000). Khat chewing is a risk factor of duodenal ulcer. Saudi medical journal, 21(9), 887-888.

[12] Rushby K. (2000). Eating the flowers of paradise: a journey through the drug fields of Ethiopia and Yemen. Arab studies journal, 10(1, 2), 185-188. 
[13] Stuyt RJ, Willems SM, Wagtmans MJ and Van Hoek B. (2011). Chewing Khat and chronic liver disease. Liver International, 31(3), 434-436.

[14] Chapman MH, Kajihara M, Borges G, O'beirne J, Patch D, Dhillon AP, Crozier A and Morgan MY. (2010). Severe, acute liver injury and Khat leaves. New England Journal of Medicine, 362(17), 1642-1644.

[15] Nasr AH and Khatri ML. (2000). Head and neck squamous cell carcinoma in Hajjah, Yemen.Saudi medical journal, 21(6), 565-568.

[16] Alhaddad OM, Elsabaawy MM, Rewisha EA, Salman TA, Kohla MAS, Ehsan NA and Waked IA. (2016). Khat-induced liver injuries: A report of two cases. Arab Journal of Gastroenterology, 17.

[17] Alvi A, Rizwan M, Sunosi RA and Jerah ABA. (2014). Does Khat chew increases the risk of Mycobacterium tuberculosis infection by macrophage immune modulation? Medical Hypotheses, 82(6), 667-669.

[18] Corkery JM, Schifano F, Oyefeso A, Ghodse AH, Tonia T, Naidoo V and Button J. (2011). 'Bundle of fun or 'bunch of problems'? Case series of Khat-related deaths in the UK. Drugs: education, prevention and policy, 18(6), 408425.

[19] Krikorian AD. (1984). Kat and its use: a historical perspective. Journal of Ethnopharmacology, 12(2), $115-178$.

[20] Brewer J. (2008). Consuming cultures, global perspectives, historical trajectories, transnational exchanges. Oxford, UK review, American Anthropologist, 110 (3), 384-385.

[21] khat-miraa-wine-takes-nairobi-by-storm. https://nairobikenya.wordpress.com/ (accessed January 2018).

[22] Fergus S, Kellett K and Gerhard U. (2015). The Khat and Meow Meow Tale: Teaching the Relevance of Chemistry through Novel Recreational Drugs. Journal of chemical education, 92, 843-848.

[23] Hardy C and Maguire S. (2010). Discourse, field-configuring events, and change in organizations and institutional fields: Narratives of DDT and the Stockholm Convention. Academy of Management Journal, 53(6), 1365-1392.

[24] Biscoe ML, Mutero CM and Kramer RA. (2004). Current policy and status of DDT use for malaria control in Ethiopia, Uganda, Kenya and South Africa. : IWMI.

[25] Daba D, Hymete A, Bekhit AA, Mohamed AMI and Bekhit AEA. (2011). Multi-residue analysis of pesticides in wheat and Khat collected from different regions of Ethiopia. Bulletin of environmental contamination and toxicology, 86(3), 336-341.

[26] Mahmoud A. (2000). The mycotoxin-producing potential of fungi associated with qat (Catha edulis) leaves in Yemen. Folia Microbiol (Praha),' 45(5), 452-456.

[27] Kristanc L and Kreft S. (2016). European medicinal and edible plants associated with subacute and chronic toxicity part I: Plants with carcinogenic, teratogenic and endocrine-disrupting effects. Food and Chemical Toxicology, 92, 150-164.

[28] Abdol KN, Mohammad JM, Ahmad RY, Vosoughi M, Farhadi M, Badri S and Daneshpajoh M. (2016). Microbial Contamination of Raw Vegetables in Ahvaz, Iran during 2014-2015. Archives of Hygiene Sciences, 5(3), $199-206$.

[29] Abegaz K, Dessie G and Ashenafi M. (2017).Microbial load and microflora of" Khat"(Cata edulis Forsk) and effect of" Khat" juice on some foodborne pathogens. The Ethiopian Journal of Health Development (EJHD), 11(1), 3-6.

[30] C SA I. (2012). Ethiopia demographic and health survey 2011. Addis Ababa, Ethiopia and Calverton, Maryland, USA: Central Statistical Agency and ICF International, 430.

[31] Ligani S and Hussein A. (2014). Determination of Organochlorine pesticide residue levels in chewable parts of the Khat (Catha edulis) Plant. Bulletin of environmental contamination and toxicology, 93(5), 591-595.

[32] Mortimore S and Wallace C. (2013). HACCP: A practical approach. Springer New York Heidelberg Dordrecht London. (eBook), 91-104.

[33] Daba D, Hymete A, Bekhit AA, Mohamed AMI and Bekhit AEA. (2011). Multi-residue analysis of pesticides in wheat and Khat collected from different regions of Ethiopia. Bulletin of environmental contamination and toxicology, 86(3), 336-341.

[34] Rushby K. (2000). Eating the flowers of paradise: a journey through the drug fields of Ethiopia and Yemen. Griffin ed. ed. New York: St. Martin's Griffin.

[35] Kasperson RE, Renn O, Slovic P, Brown HS, Emel J, Goble R, Kasperson JX and Ratick S. (1988). The social amplification of risk: A conceptual framework. Risk analysis, 8(2), 177-187. 
[36] European Union (EU) Pesticides database. http://ec.europa.eu/food/plant/pesticides/eu-pesticides/ (accessed October 2018)

[37] Santarelli GA, Migliorati G, Pomilio F, Marfoglia C, Centorame P, D'agostino A, D'aurelio R, Scarpone R, Battistelli $\mathrm{N}$, Di Simone F, Aprea G and Iannetti L. (2018). Assessment of pesticide residues and microbial contamination in raw leafy green vegetables marketed in Italy. Food Control, 85, 350-358.

[38] Carmichael I, Harper I, Coventry M, Taylor P, Wan J and Hickey M. (1998). Bacterial colonization and biofilm development on minimally processed vegetables. Journal of applied microbiology, 85(S1), 13-20.

\section{How to cite this article}

Beyene WA, L. Brimer. A. Dalsgaard and T.Belachew. (2020). Chemical and microbiological hazards of Khat (Catha edulis) from field to chewing in Ethiopia. GSC Biological and Pharmaceutical Sciences, 11(1), 24-35. 